\title{
ALTERATIONS IN THE LIPID AND SOLUBLE SUGAR CONTENT OF MELANOXYLON BRAUNA SEEDS DURING NATURAL AND ACCELERATED AGEING ${ }^{1}$
}

\author{
VIVIANA BORGES CORTE2; EDUARDO EUCLYDES DE LIMA E BORGES3; \\ JOSÉ FRANCISCO DE CARVALHO GONÇALVES ${ }^{4}$; MIRIAN SOUSA SILVA ${ }^{5}$
}

\begin{abstract}
The decay of seeds is irreversible and at best can only be delayed by applying techniques that reduce the velocity of the metabolic reactions involved. There is little information on the biochemistry of tropical forest tree seeds related to their storability. It was investigated the influence of the composition of lipids and soluble sugars of two storage compartments, the cotyledons and the embryonic axis, of Melanoxylon brauna Schot. (Leguminosae- Caesalpinioideae), a hardwood known as black brauna, seeds stored at $20^{\circ} \mathrm{C}$ for $0,3,6,9$ and 12 months (natural ageing) and for 0 , $24,48,72$ and 96 hours at $40^{\circ} \mathrm{C}$ (accelerated ageing). The levels of fatty acids and monosaccharides varied differentially in each of the embryo storage compartments. Changes in oligosaccharide levels were similar for both types of ageing, diminishing in both compartments. Ageing can be attributed to the significant decrease of oligosaccharides and the increase of glucose in both types of ageing and both embryo compartments.
\end{abstract}

Index terms: carbohydrates, forest, lipids, native species, storage

\section{ALTERAÇÕES NO CONTEÚDO DE RESERVAS EM SEMENTES DE Melanoxylon brauna DURANTE O PROCESSO DE ENVELHECIMENTO NATURAL E ACELERADO}

RESUMO - A deterioração de sementes é fato irreversível, podendo, no máximo, ser retardada com aplicação de técnicas que reduzam a velocidade das reações metabólicas envolvidas. Informações bioquímicas sobre sementes florestais tropicais relacionadas à sua armazenabilidade são escassas. O objetivo no presente trabalho foi pesquisar a influência da composição de lipídios e de açúcares solúveis, nos dois compartimentos, eixo embrionário e cotilédones, de sementes de brauna (Melanoxylon brauna - Leguminosae-Caesalpinoideae) armazenadas por 0, 3, 6, 9 e 12 meses a $20^{\circ} \mathrm{C}$ (envelhecimento natural) e durante $0,24,48$ e 72 horas à $40{ }^{\circ} \mathrm{C}$ (envelhecimento acelerado). Os teores dos ácidos graxos e dos monossacarídeos variam diferentemente durante ambos os tipos de armazenamento em cada um dos compartimentos. As alterações nos teores de oligossacarídeos são semelhantes em ambos os tipos de envelhecimento e apresentam decréscimo em ambos os compartimentos. Pode-se atribuir comportamento marcante no envelhecimento aos oligossacarídeos que mantém significativa queda e da glicose que aumenta em ambos os tipos de envelhecimento e compartimento analisado do embrião.

Termos para indexação: floresta, armazenamento, carboidratos, lipídios, espécies nativas.

${ }^{1}$ Submetido em 27/08/2009. Aceito para publicação em 24/05/2010.

${ }^{2}$ Bióloga, Dr., Professora Substituta Departamento de Teorias e Práticas Educacionais, Universidade Federal do Espírito Santo, UFES, Vitória, ES, 29075-910, E-mail: viviborgescorte@yahoo.com.br.

${ }^{3}$ Eng. Florestal, Professor Dr, Departamento de Eng. Florestal, Universidade Federal Viçosa, UFV, av. P. H. Rolfs, 36570-000, Viçosa,
MG, E-mail: elborges@ufv.br.

${ }^{4}$ Eng. Agr., Pesquisador Inst. Nac. Pesq. Amazônia (MCT-INPA), Lab. Fisiol. Bioq. Vegetal - INPA V/8, Av. Efigênio Sales, caixa postal 476, 69011-970, Manaus, AM. E-mai: jfc@inpa.gov.br.

${ }^{5}$ Eng. Florestal, MS. Departamento de Engenharia Florestal, Universidade de Viçosa, Av. P.H Rolfs, 36570-000, Viçosa, MG. E-mail: mirianfloresta@, gmail.com 


\section{INTRODUCTION}

The black braúna (Melanoxylon brauna Schott. (Leguminosae-Caesalpinioideae), is a native Brazilian tree known for the quality and durability of its wood. It occurs in the Brazilian Atlantic Forest in the south of Bahia state and in the states of São Paulo, Minas Gerais (Lorenzi, 1992), Goiás, Rio Grande Rio do Norte, Mato Grosso, Maranhão and Piauí (IBAMA, 2008). However, it has been classified as vulnerable in the official Brazilian endangered flora list (Lista Oficial das Espécies da Flora Brasileira Ameaçadas de Extinção: IBAMA, 2008) due to excessive exploitation without replanting.

High temperatures and humidity during seed storage contribute to the acceleration of deterioration (McDonald, 1999) by degenerative metabolism. The reserves stored in the seeds consist of complex molecules (Bewley and Black, 1994), the proportion of which varies between species and among species of the same family (Borges and Rena, 1993). Carbohydrates, proteins and lipids are among the macromolecule essential to germination because free fatty acids and soluble sugars are degraded during ageing (McDonald, 1999) and cannot be used for biosynthesis and energy production (Marcos Filho, 2005), which prejudices germination and seedling survival. Furthermore, reduction in sucrose, raffinose and stachyose levels can affect the protective effect sugars have on membrane integrity (Ferreira and Borguetti, 2004), while increased levels of reducing sugars can cause the deterioration of protein components (Marcos Filho, 2005).

Information regarding the process occurring during healthy ageing of forest species seeds is scarce, variable and, in some cases, contradictory. Some authors affirm a high correlation between natural and accelerated ageing, with the promoter mechanisms of the deterioration occurring during ageing being the same in both cases and varying only in the speed of the process (Delouche and Baskin, 1973; Santos and Paula, 2007). However, other authors state that artificial (accelerated) ageing does not faithfully reproduce all the metabolic events happening during the storage of some species (Bailly et al., 1996; Borges et al., 2000; Fanan et al., 2006).

The deterioration processes occurring during the ageing of M. brauna seeds has not been well-studied, so our objective was to quantify and compare the alterations occurring in the lipids and carbohydrates of these seeds during the natural and accelerated ageing. For this investigation we examined the lipid and soluble sugar composition of two storage compartments, the cotyledons and the embryonic axis of $M$. brauna seeds.

\section{MATERIAL AND METHODS}

Seeds collected from 15 M. brauna trees located in the Viçosa region of the Brazilian state of Minas Gerais were used in this study. Immature, deteriorated or damaged seeds were eliminated, and before each experiment the selected seeds were immersed in a solution of $0.5 \%(\mathrm{w} / \mathrm{v})$ Captan for 60 seconds.

All the analyses used recently collected unstored seeds (storage time $=$ zero) as controls. To assess the effects of natural ageing, analyses were made every three months during 12 months of storage in plastic packages placed inside cardboard tubes and maintained at $20{ }^{\circ} \mathrm{C}$ and $60 \%$ of relative humidity $(\mathrm{RH})$. For the accelerated ageing experiments seeds were placed in plastic boxes ('gerbox') containing $40 \mathrm{~mL}$ of distilled water separated from the seeds by nylon screens, the boxes then being placed in an artificial ageing chamber at $45{ }^{\circ} \mathrm{C}$ and $100 \% \mathrm{RH}$. The ageing times were $0,24,48$ and 72 hours. This study was undertaken in conjunction with the Laboratory for the analysis of Forest Seeds of the Department of Forest Engineering of the Federal University of Viçosa (Laboratório Análise de Sementes Florestais do Departamento de Engenharia Florestal da Universidade Federal de Viçosa).

\section{Fatty acid quantification}

Samples of M. brauna embryonic axes and cotyledons were dried, macerated in a porcelain mortar and pestle, placed in filter paper cartridges and treated with oil which was then cold-extracted with petroleum ether for $24 \mathrm{~h}$ in a Soxhlet extractor (Silva, 1990) and the samples stored at $-20{ }^{\circ} \mathrm{C}$ until quantification. Fatty acids were quantified by conversion to their respective methalic esters (Borges et al., 2000). Briefly, $20 \mathrm{mg}$ samples of the cotyledon or embryonic axis samples were dissolved in $0.5 \mathrm{~mL}$ of tetrahydrofuran (THF) to which was added $1 \mathrm{~mL}$ of 0.5 $\mathrm{M}$ sodium methoxide solution prepared with metallic sodium and anhydrous methanol. The tubes were placed in a water bath and maintained at $50{ }^{\circ} \mathrm{C}$ for 10 minutes, after which $50 \mu \mathrm{L}$ of glacial acetic acid and $3 \mathrm{~mL}$ of distilled water were added and the sample transferred to a separation funnel and the methalic esters extracted twice with $5 \mathrm{~mL}$ of hexane. The organic phase was dried with anhydrous sodium sulfate containing $10 \%$ solid potassium carbonate and the solvent removed in a rotary evaporator, 
the methalic esters being resuspended in $1 \mathrm{~mL}$ of hexane. It was injected $1 \mu \mathrm{L}$ of the methalic esters samples into a Shimadzu CG14-A gas chromatograph equipped with a flame ionization detector (FID) and a Chromatopac C-R6A integrator. To quantify the fatty acids It was used a Shimadzu $50 \mathrm{~m} \mathrm{X} 0.2 \mathrm{~mm}$ (diameter) melted silica capillary column with hydrogen as the carrier gas at a flow rate of $30 \mathrm{~mL}$ $\mathrm{min}^{-1}$ with the injector at $220{ }^{\circ} \mathrm{C}$ and the detector at 230 ${ }^{\circ} \mathrm{C}$. The temperature of the column was programmed for an isothermic temperature of $190{ }^{\circ} \mathrm{C}$ for 60 seconds followed by elevation of $2{ }^{\circ} \mathrm{C} \mathrm{min}{ }^{-1}$ until an isothermic maximum of $200{ }^{\circ} \mathrm{C}$ for 20 minutes.

\section{Monosaccharide and oligosaccharide quantification}

Mono and oligosaccharides were extracted from embryos and cotyledons according to a modified standard methodology (Black et al. 1996). Briefly, the samples were dried, ground, homogenized in $80 \%(\mathrm{v} / \mathrm{v})$ ethanol, centrifuged and the supernatant separated and retained, this process being repeated three times for each sample. The three supernatants for each sample were pooled, evaporated to dryness and the soluble carbohydrates resuspended in ultra-pure water. For monosaccharide quantification, $500 \mu \mathrm{L}$ samples were used to prepare alditol acetate according to the method of Englyst and Cummings (1984). Chromatograms were obtained using a Shimadzu CG14-A gas chromatograph equipped with a flame ionization detector (FID) and a Chromatopac C-R6A integrator. For separation, it was injected $1 \mu \mathrm{L}$ of sample into a moderately polar column of $50 \%$ cyanopropyl phenyl dimethyl siloxane with an hydrogen carrier gas flow rate of $15 \mathrm{~mL} \mathrm{~min}^{-1}$ and the injector at $250{ }^{\circ} \mathrm{C}$, the column at $220^{\circ} \mathrm{C}$ and the detector at $275^{\circ} \mathrm{C}$. For oligosaccharide quantification, $100 \mu \mathrm{L}$ soluble carbohydrate samples were concentrated to total dryness in a lyophilizer, resuspended in methanol, filtered to remove protein and pigment residues and again concentrated in the lyophilizer. Oligosaccharides were separated and quantified by dissolving the concentrated samples in $500 \mu \mathrm{L}$ of ultrapure water and injecting $20 \mu \mathrm{L}$ aliquots into a Shimadzu high performance liquid chromatograph (HPLC) equipped with an HPX-42C Aminex $300 \times 7.8 \mathrm{~mm}$ Column at an oven-temperature $40{ }^{\circ} \mathrm{C}$ and an RID-10A refraction index detector using isocratic analysis and a water mobile phase and an analysis time of 20 minutes.

\section{Seed water content}

Water content was determined every three months by drying three replicates of 20 seeds at $105^{\circ} \mathrm{C}$ for 24 hours (BRASIL, 1992).

\section{Statistical analysis}

The experiment design was entirely randomized with three replicates. The data was submitted to analysis of variance (ANOVAR) and regression analysis at the 5\% significance level using the Statistica program Version 6 (StatSoft ${ }^{\square}$ 2001).

\section{RESULTS AND DISCUSSION}

Regarding fatty acids, the caproic acid content of the embryonic axis increased during storage up to the third month and then remained roughly constant until the end of the experiments at 12 months (Figure 1a), while caproic acid in the cotyledons increased continuously until the ninth month and then remained constant in the twelfth month. Myristic acid showed a significant increase during storage in both the cotyledons and the embryonic axis, with similar values and patterns for both these storage compartments (Figure 1b). Palmitic acid decreased slightly in the embryonic axis until the third month and then stabilized until the twelfth month (Figure 1c), while in the cotyledons the levels of this fatty acid decreased until the sixth month but then increased up to the end of the storage period at twelve months (Figure 1c). Unlike the fatty acids described above, the stearic acid content during storage was different in the embryonic axis and the cotyledons (Figure 1d), with only a small variation in the embryonic axis but in the cotyledons there was a significant decrease until the sixth month and a subsequent increase until the end of the storage period (Figure 1d). Oleic acid and linoleic acid showed a similar pattern (Figures 1e and 1f) to that of stearic acid (Figure 1d). The oleic acid content in the cotyledons decreased until the ninth month but showed a small increase in the twelfth month, while in the embryonic axis the levels remained constant until the sixth month and then decreased until the twelfth month (Figure 1e). The linoleic acid values for the cotyledons showed a similar pattern to that of stearic acid, while in the embryonic axis the values varied little during the twelve months of storage (Figure 1f). Marcos Filho (2005) reported that alterations in the chemical composition of seeds is common, occurring gradually and at variable intensities and speeds, and eventually progresses to deterioration. These processes involve alterations in reserve compounds and in the synthesis and activity of enzymes, all of which directly influence the chemical composition of the seeds. It has been shown that seeds of the Pará rubber tree (Hevea brasiliensis) showed a 
tendency for reduced oleic acid, linoleic acid and linolenic acid content when stored under the same conditions as we stored M. brauna seeds (Paula et al., 1997). Furthermore, it has also been reported that moist-stored seeds of Inga vera, subsp. Affinis, also a member of the Fabaceae, showed agglutination of oleosomes concomitant with a reduction in seed quality, although the lipid content of these seeds was not quantified (Faria et al. 2006).
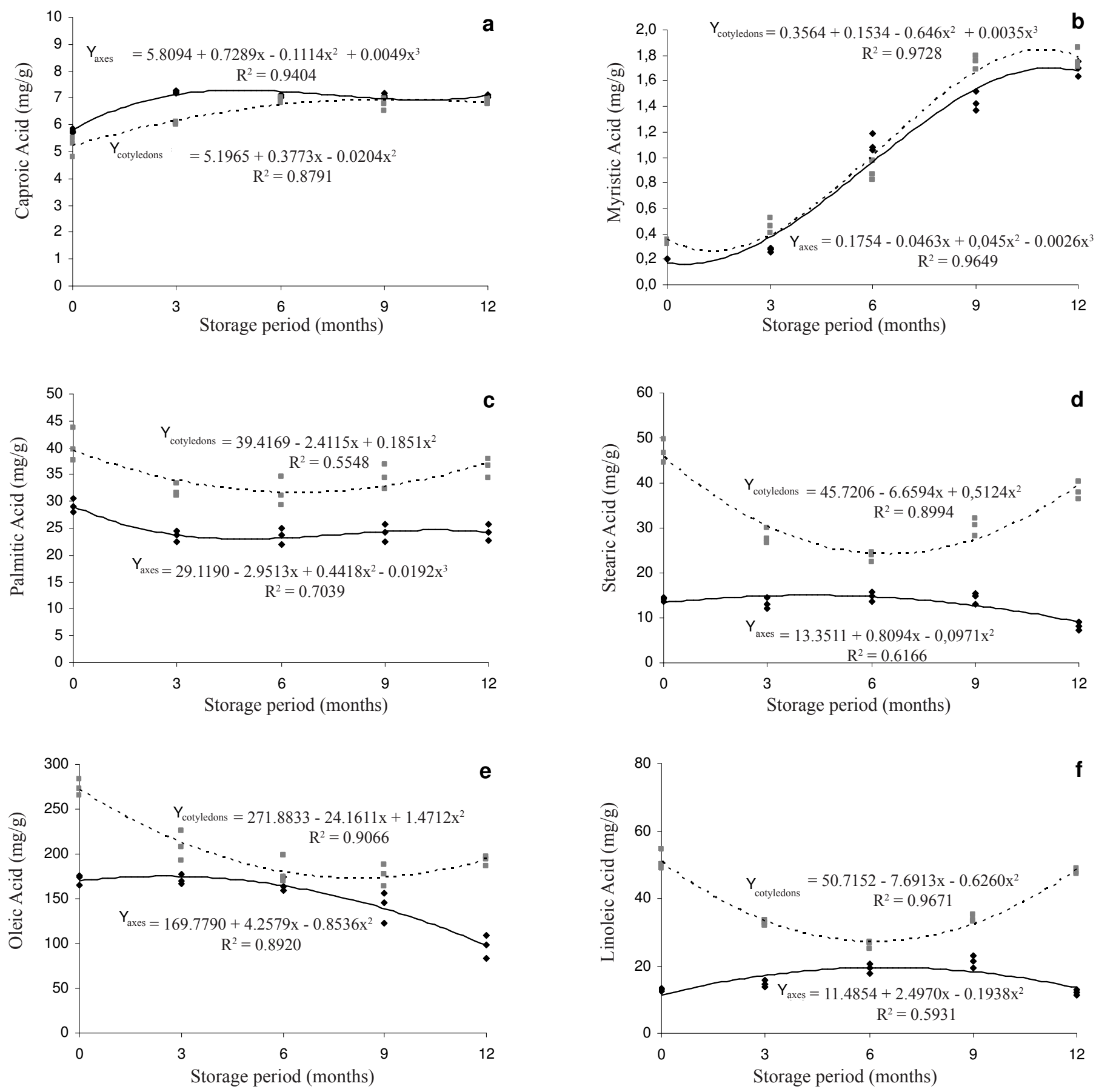

FIGURE 1. Fatty acid levels in Melanoxylon brauna seeds subjected to natural ageing in embryonic axis, $\bullet$ cotyledon 
In accelerated ageing experiments, caproic acid levels remained practically unaffected and very similar in both the embryonic axis and the cotyledons (Figure 2a). The myristic acid content of the embryonic axis was minimally reduced but there was a large decrease in the cotyledons where the myristic acid levels at 72 hours reached a similar value to that in the embryonic axis (Figure 2b). Palmitic acid levels in the cotyledons increased during the first 24 hours of accelerated ageing but then decreased until the end of the experiment at 72 hours (Figure 2c), while in the embryonic axis the levels initially remained stable before decreasing during the rest of the accelerated ageing experiment. These results indicate that the storage
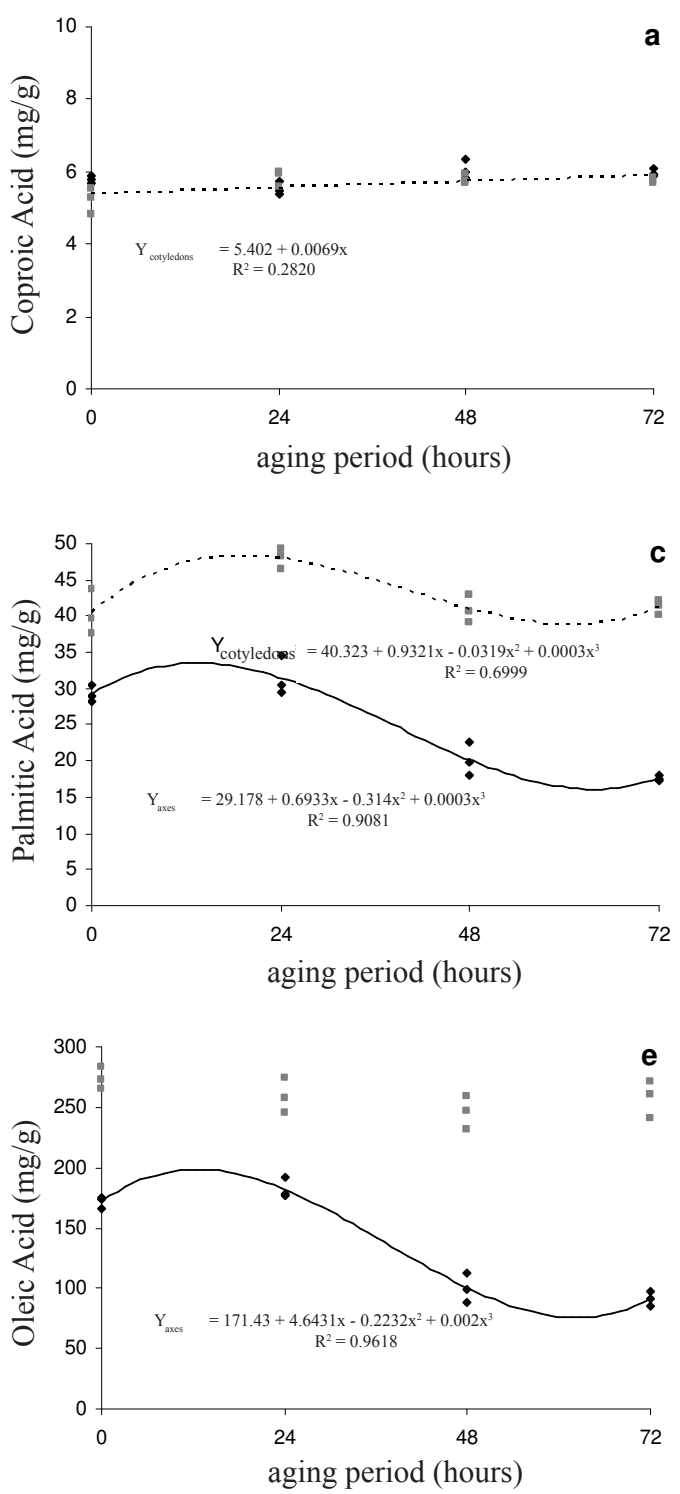

compartments showed very similar tendencies. Stearic acid levels decreased slightly in the cotyledons during accelerated ageing but were stable in the embryonic axis for the first 24 hours, after which the levels dropped (Figure 2d). Oleic acid content reduced significantly in the embryonic axis, while in the cotyledons the variation was not statistically significant (Figure 2e). Linoleic acid vales did not vary greatly in the embryonic axis or the cotyledons, with just slightly elevated levels during the first 24 hours followed by stable values for the rest of the experiment (Figure 2f). Thapliyal and Connor (1997) also observed small variations in the total percentage of fatty acids during period of accelerated ageing.
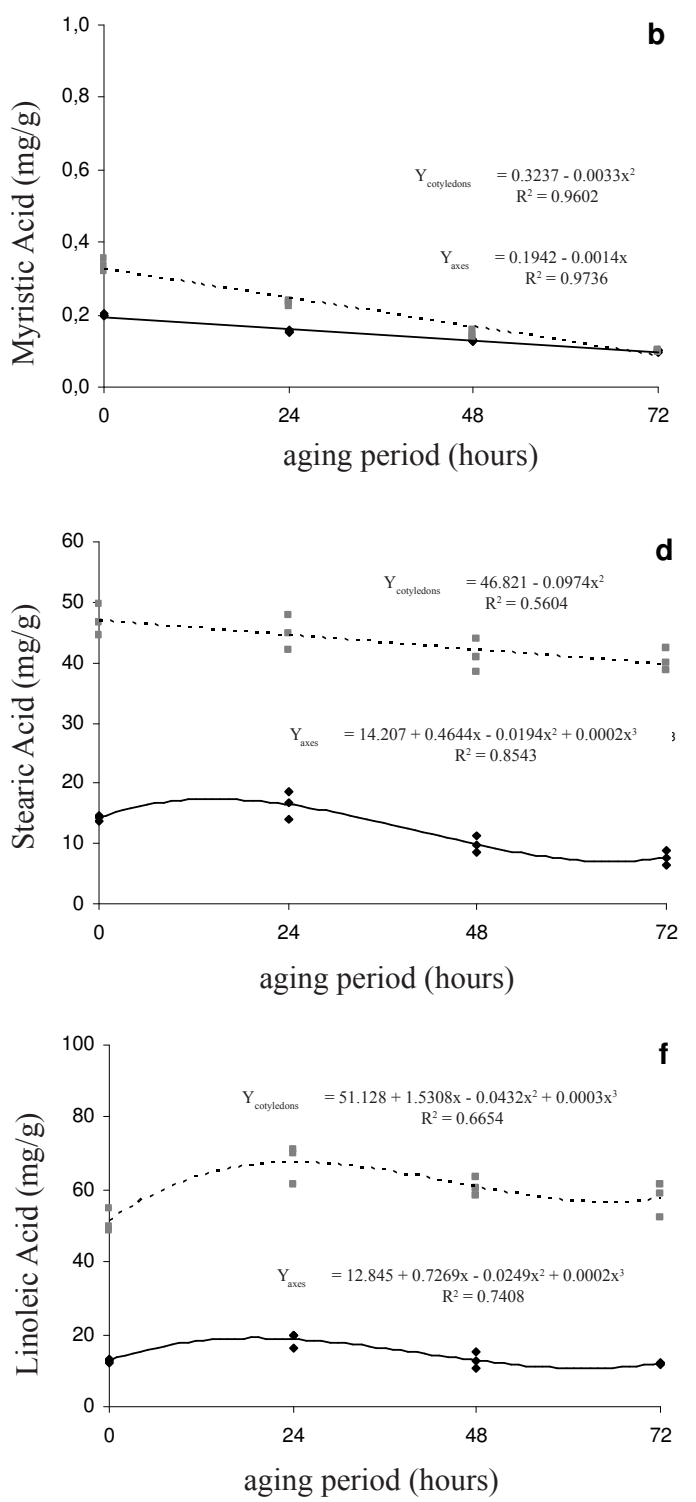

FIGURE 2. Fatty acid levels in Melanoxylon brauna seeds subjected to accelerated ageing in embryonic axis, cotyledon 
It is interesting to note that, except for caproic acid, the levels of all the fatty acids investigated were higher in the cotyledons than in the embryonic axis during natural and accelerated ageing. The caproic acid levels were similar to that of seeds maintained in storage (i.e. the control seeds), these seeds also presented myristic acid values which were similar in both storage compartments. We also observed that, except for oleic acid, the variations in the levels of fatty acids in each storage compartment during natural ageing varied independently. In the case of oleic acid, however, values decreased in the embryonic axis while increasing in the same proportion in the cotyledons during natural ageing. During accelerated ageing, utilization of fatty acids in one storage compartment showed no relationship with regard to the other compartment. In general, the tendency was towards reduced, or stable, levels of fatty acids in the embryonic axis during both types of ageing. The only fatty acid levels to decrease were oleic acid values in both natural and accelerated ageing and palmitic aced in the accelerated ageing experiments. Several authors have tried to correlate the processes occurring in the deterioration of seeds with changes in fatty acid levels. For the lipid fraction of plasma membranes, polyunsaturated fatty acids such as linoleic acid and linolenic acid are more susceptible to oxidative degradation (Bewley and Black, 1994). Research has shown reduced fatty acid content in soybean (Glycine max) seeds during natural ageing and in maize (Zea mays) and sunflower (Helianthus annuus) during accelerated ageing (Trawatha et al., 1995; Basavarajappa et al., 1991; Halder et al., 1983). In this experiments with M. brauna, it was found a greater tendency towards decreased fatty acid levels than towards increased levels.

In terms of monosaccharides, in the natural ageing experiments the levels of the xylose, mannose and galactose were significantly decreased in the embryonic axis of the stored seeds (Figures 3a, 3b and 3c), while there was an increase in glucose values in both storage compartments and increased xylose content in the cotyledons (Figures 3d and $3 \mathrm{a}$, respectively). Galactose levels in the cotyledons was significantly increased until the third month of storage, followed by a small reduction with subsequent stabilization up to the twelfth month (Figure 3c). Only the xylose values showed a positive correlation between the two storage compartments but the relationship in xylose levels was inverse, suggesting the transfer of xylose between the storage compartments. For the other monosaccharides the trend seemed to be restricted to the cotyledons and the embryonic axis, with, in most cases (the exception being for the glucose), the embryonic axis having the lowest monosaccharide levels at the end of the natural storage period. In general, there was a significant degradation of xylose, mannose and galactose in the embryonic axis during natural storage. The possibility of monosaccharide leeching from the embryonic axis can be discarded due to the stability of, or increased, monosaccharide levels in the cotyledons and the low water content of the seeds $(11 \%$ $\mathrm{RH}$ at the start of the experiments and $13 \% \mathrm{RH}$ at twelve months) which would have prevented leaching from both compartments. The only other alternatives are respiration or conversion into secondary products such as phenols or proteins. Faria et al. (2006) reported the occurrence of reduced starch levels in radicle cells during the reduction of quality of $I$. vera seeds. Although we did not quantify alterations in starch levels in M. brauna, it is reasonable to assume that conversion of starch to glucose may have been the reason for the increased glucose levels seen in our experiments.

During accelerated ageing the xylose level in the embryonic axis increased up to 48 hours and stayed approximately stable for the next 24 hours until the experiment ended at 72 hours (Figure 4a), while the xylose content of the cotyledons remained constant for the first 48 hours and then increased. Mannose levels in the embryonic axis and the cotyledons (Figure $4 \mathrm{~b}$ ) were different, with values close to those before the artificial ageing experiments and with the values in the embryonic axis showing a slight increase while those in the in the cotyledons remained stable. The galactose values were practically stable in the embryonic axis during artificial ageing but increased in the cotyledons where it reached values close to that in the embryonic axis (Figure 4c). Elevated galactose values can result in protein degradation and a consequent decrease in the quality of artificially aged seeds since galactose is one of the more reactive sugars involved in Amadori isomerization or rearrangement reactions (Bernal-Lugo and Leopold, 1992). It is interesting to note, however, that Amadori reactions are unlikely to occur in naturally aged $M$. brauna seeds, because in this case we found that galactose levels increased only initially and then showed a tendency towards a significant fall in the embryonic axis (Figure 3c). During accelerated ageing, glucose presented the lowest values of all the monosaccharides, with the glucose concentrations in each compartment being increasing but different (Figure 4d). In general, in accelerated ageing there was no reduction in the monosaccharide reserves of either compartment, unlike the case for naturally aged M. brauna seeds. 

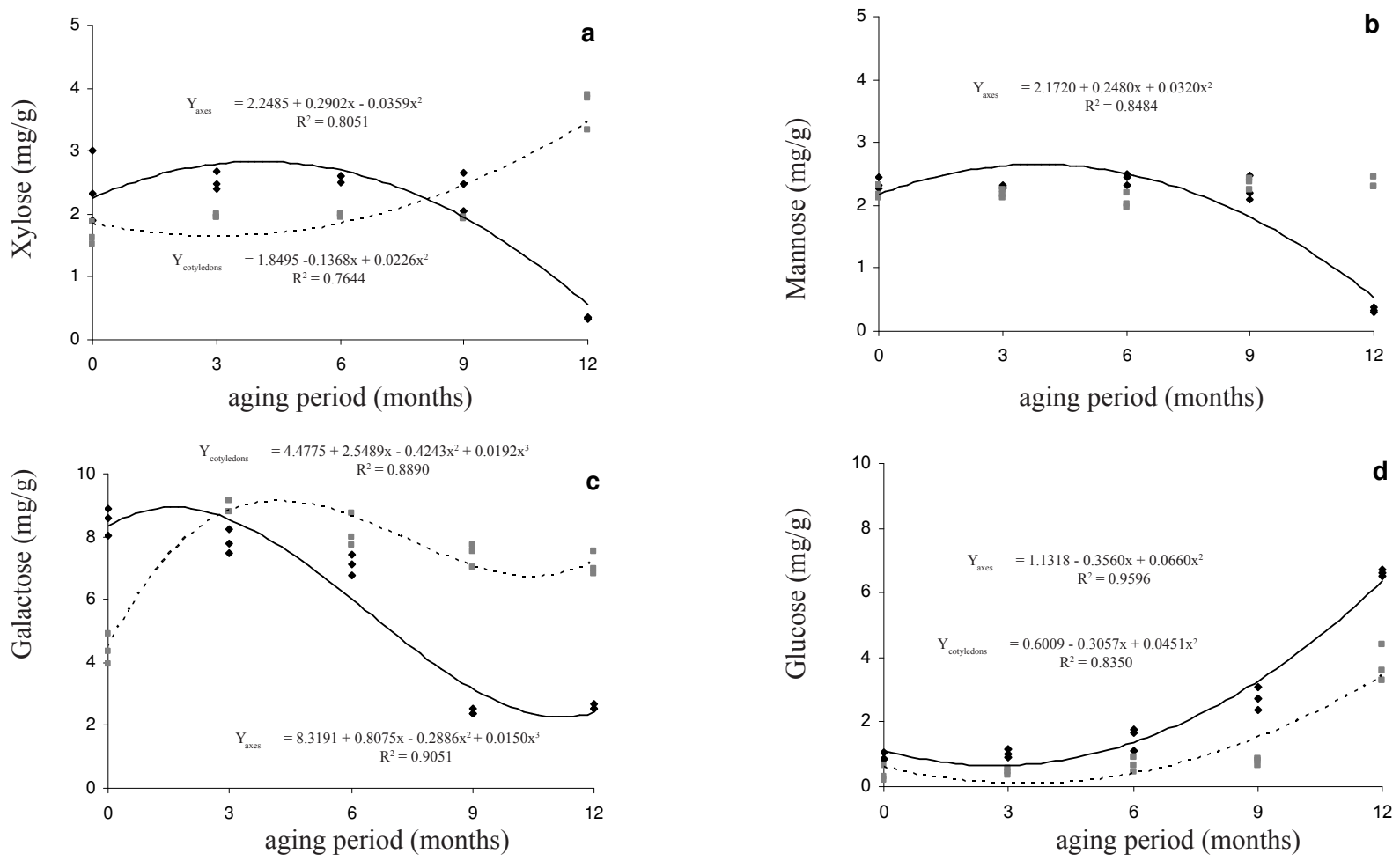

FIGURE 3. Monosaccharide levels in Melanoxylon brauna seeds subjected to natural ageing in embryonic axis, $\diamond$ cotyledon!
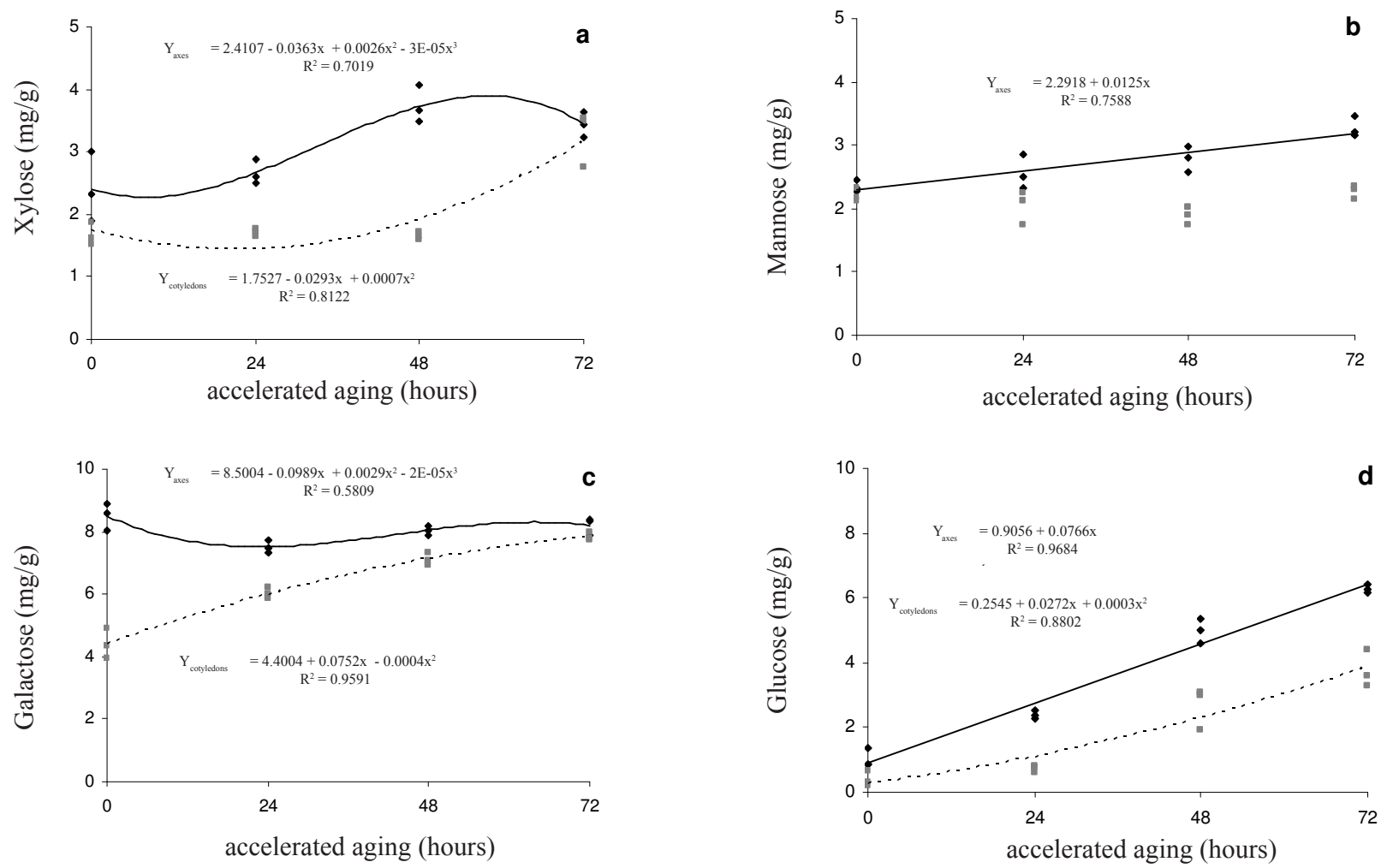

FIGURE 4. Monosaccharide levels in Melanoxylon brauna seeds subjected to accelerated ageing embryonic axis, $\diamond$ cotyledon $\square$. 
The behavior of the seeds regarding monosaccharide utilization in both compartments was different during the natural ageing and accelerated ageing of $M$. brauna seeds. During the ageing of seeds there is a gradual liberation of reducing sugars that accelerate deterioration by inducing the destruction of protein components and this affects seed viability (Locher and Buchelli, 1998; Marcos Filho, 2005). Enzymes such as invertase (beta-fructofuranosidase, EC 3.2.1.26) and alpha-galactosidase (EC 3.2.1.22) can promote the liberation of reducing sugars but require relatively high levels of hydration in order to function (Wettlaufer and Leopold, 1991). We believe that such hydration was probably facilitated in the M. brauna seeds exposed to high relative humidity in the accelerated ageing experiments, with increased enzyme activity being the reason for the higher levels of reducing sugars which we found in the seeds subjected to accelerated ageing compared to those which were naturally aged.

For the oligosaccharides the results were similar for both types of ageing, with the levels in the embryonic axis always being higher than that in the cotyledons. At the end of 12 months natural ageing or 72 hours accelerated ageing the oligosaccharide values in each compartment were almost the same, possibly due to their greater use in the embryonic axis as compared to the cotyledons (Figure 5a, b, c, d, and, and f). According to Dey (1981), the trisaccharide raffinose is stored in the reserve organs of seeds and is either hydrolyzed by alpha-galactosidase present in the embryo of stored dry seeds (Feurtado et al., 2001) or used as a precursor for the synthesis of other oligosaccharides. The raffinose family oligosaccharides are composed of linked sucrose and galactose molecules which can be hydrolyzed free sucrose and galactose (Cruz et al., 1981).
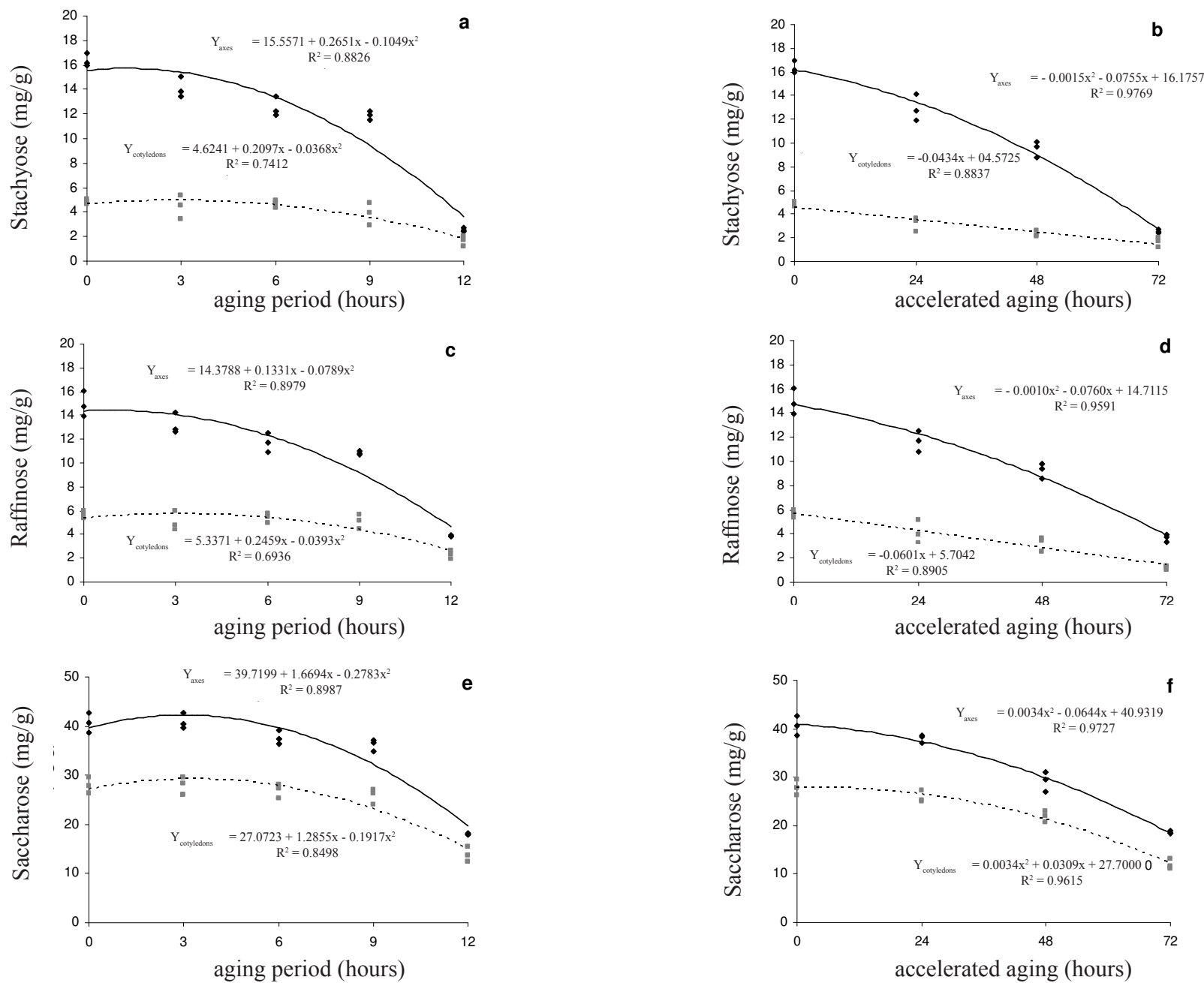

FIGURE 5. Oligosaccharide levels in Melanoxylon brauna seeds submitted to natural and accelerated ageing in embryonic axis, $\diamond$ cotyledon $\square$. 
Glucose levels in the embryonic axis rose in both ageing experiments, while galactose levels decreased during natural ageing but remained stable during accelerated ageing. The reduced galactose and mannose levels in the embryonic axis which occurred in naturally aged seeds was probably to avoid possible deleterious effects due to the presence of these sugars. Borges et al. (2004) reported that galactose inhibited alpha-galactosidase activity in the embryonic axis and cotyledons of seeds of the native Brazilian tree Caesalpinia peltophoroides Benth. The reduction in the levels of galactose, a fundamental component of cell walls, and the reduced mannose content during normal ageing and its elevation during accelerated ageing suggests that oligosaccharides are being used for respiration and not for biosynthesis.

Several authors have correlated decreased levels of soluble sugar and starch and the accumulation of reducing sugars with seed deterioration (Braccini et al., 2001; Marcos Filho, 2005), possibly due to less substrate being available for respiration and hence a reduction in germination and vigor (Bernal-Lugo and Leopold, 1992; Locher and Bucheli, 1998; Marcos Filho, 2005). The large amount of soluble carbohydrates in C. peltophoroides seeds appears to function not only as an energy supply during germination but to also be a factor in the ability of these seeds to survive prolonged storage (Corte et al.,2006). This hypothesis is supported by the fact that soluble sugars are known to have a role in the maintenance of membranes and protein integrity when seeds are maintained at low humidity (Carpenter et al., 1987). Garcia et al. (2006) reported that Caesalpinia echinata Lam. (Brazilwood or Pau-Brasil in Portuguese) seeds maintained under natural conditions not only lost the capacity to germinate but also showed reduced glucose and fructose levels. Hellmann et al. (2008), however, found no relationship between soluble sugar levels and the germinative capacity of $C$. echinata seeds stored at low temperature, suggesting that carbohydrate metabolism may vary in accord with the stress to which seeds are submitted.

It appears that in spite of the fact that seed embryo is latent indicate that in spite of the fact that seed embryo is latent its vital activities do not cease entirely but are probably dependent on the temperature and humidity of the atmosphere in which the seeds are stored.

\section{CONCLUSIONS}

The fatty acid and monosaccharide content of $M$. brauna seeds varied differently during natural and accelerated ageing both in the embryonic axis and the cotyledons.

The alterations in the oligosaccharides levels were similar in both natural and accelerated ageing, decreasing in both the embryonic axis and the cotyledons.

The significant reduction in oligosaccharide content and the increase in glucose levels in both the embryonic axis and the cotyledons were important factors in ageing.

\section{REFERENCES}

BAILLY, C; BENAMAR, A; CORBINEAU, F; COME, D. Changes in malondialdehyde content and in superoxide dismutase, catalase and glutathione reductase activities in sunflower seeds as related to deterioration during accelerated aging. Physiologia Plantarum, v.97, p.104-110, 1996.

BASAVARAJAPPA, B.S.; SHETTY, H.S.; PRAKASH, H.D. Membrane deterioration and other biochemical changes associated with accelerated aging of maize seeds. Seed Science and Technology, v.19, n.2, p.279-286, 1991.

BERNAL-LUGO, I.; LEOPOLD, A.C. Changes in soluble carbohydrates during seed storage. Plant Physiology, v.98, n.3, p.1207-1210, 1992.

BEWLEY, J.D. BLACK, M. Seeds: physiology of development and germination. New York: Plenum Press, 1994. 445p.

BLACK, M.; CORBINEAU, F.; GRZESIK, M.; GUY, P.; CÔME, D. Carbohydrate metabolism in the developing and maturing wheat embryo in relation to its desiccation tolerance. Journal of Experimental Botany, v.47, p.161$169,1996$.

BORGES, E.E.L.; BORGES, R.C.G.; BUCKERIDGE, M.S. Alterações nas composições de carboidratos e de ácidos graxos em sementes de jacarandá-da-bahia osmocondicionadas. Revista Brasileira de Fisiologia Vegetal, v.12, n.1, p.10-16, 2000.

BORGES, E.E.L.; RENA, A.B. Germinação de sementes. In: AGUIAR, I.B.; PIÑA-RODRIGUES, F.C.M.; FIGLIOLIA, M.B. (Coord.) Sementes florestais tropicais. Brasília, DF: ABRATES, 1993. p.83-136.

BORGES, E.E. L; REZENDE, S.T.; BORGES, R.C.G.; 
PEREZ, S.C.J.G.A. Caracterização de alfa-galactosidase e sua relação com a germinação das sementes de Platymiscium pubecens Michel, var. pubescens (tamboril da mata). Revista Brasileira de Sementes, v.26, n.2, p.82-90, 2004.

BRACCINI, A.L.; BRACCINI, M.C.L.; SCAPIM, C.A. Mecanismos de deterioração das sementes: aspectos bioquímicos e fisiológicos. Informativo ABRATES, v.11,n.1,p.10-15, 2001.

BRASIL. Ministério da Agricultura e Reforma Agrária. Secretaria Nacional de Defesa Agropecuária. Departamento Nacional de Defesa Vegetal. Coordenação de Laboratório Vegetal. Regras para análise de sementes. Brasília, DF, 1992. 365p.

CARPENTER, J.F.; CROWE, L.M.; CROWE, J.H. Stabilization of phosphofructokinase with sugars during freeze-drying. Biochemica et Biophysica Acta, v.923, p.109-115, 1987.

CORTE V.B, BORGES E.E.L, PONTES C.A, LEITE I.T.A., VENTRELLA M.C., MATHIAS, A.A. Mobilização de reservas durante a germinação das sementes e crescimento das plântulas de Caesalpinia peltophoroides Benth. (Leguminosae-Caesalpinoideae). Revista Árvore, v.30, n.6, p.941-949, 2006.

CRUZ, R.; BATISTELA, J.C.; WOSLACKI, G. Microbial $\alpha$-galactosidase for soy milk processing. Journal of Food Science, v.46, n.4, p.1126-1200, 1981.

DELOUCHE, J.C.; BASKIN, C.C. Accelerated aging techniques for predicting the relative storability of seed lots. Seed Science and Technology, v.1, n.2, p.427-452, 1973.

DEY, P.M. Alpha-galactosidase from sweet chestnut seeds. Phytochemistry, v.20, p.1493-1496, 1981.

ENGLYST, H.N.; CUMMINGS, J.H. Simplified method for the measurement of non-starch polysaccharides by gas-liquid chromatography of constituent sugar as alditol acetates. Analyst., v.109, p.937-942, 1984.

FANAN, S.; MEDINA, P.F.; LIMA, T. C.; FILHO, J. M. Avaliação do vigor de sementes de trigo pelos testes de envelhecimento acelerado e de frio. Revista Brasileira de Sementes, v.28, n.2, p.152-158, 2006.

FARIA, J.M.R.; DAVIDE, L.C.; SILVA, E.A.A.; DAVIDE, A.C.; PEREIRA, R. ; van LAMMEREN, A.A.
M.; HILLHORST, H.W.M. Physiological and cytological aspects of Inga vera subsp. affinis during storage. Brazilian Journal Plant Physiology, v.18, n.4, p.503-513, 2006.

FERREIRA, A.G.; BORGHETTI, F. Germinação: do básico ao aplicado. Porto Alegre: Artmed, 2004. 323p.

FEURTADO, J.A.; BANIK, M.; BEWLEY, J.D. The cloning and characterization of alpha-galactosidase present during and following germination of tomato (Lycopersicon esculentum Mill.) seed. Journal of Experimental Botany, v.52, n.359, p.1239- 249, 2001.

GARCIA, I.S.; SOUZA, A.; BARBEDO, C.J.; DIETRICH, S.M.C.; FIGUEIREDO-RIBEIRO, R.C.L. Changes in soluble carbohydrate during storage of Caesalpinia echinata Lam. (brazilwood) seeds an endangered leguminous tree from the brazilian atlantic forest. Brazilian Journal Biology, v.66, n.2B, p.739-745, 2006.

HALDER, S.; KOLE, S.; GUPTA, K. On the mechanism of sunflower seed deterioration under two different types of accelerated ageing. Seed Science and Technology, v.11, p.331-339, 1983.

HELLMANN, M.E.; MELLO, J.I.O.; BARBEDO, C.J.; FIGUEIREDO-RIBEIRO, R.C.L. Variações dos carboidratos de reserva de sementes de Caesalpinia echinata (pau-brasil) armazenadas sob diferentes temperaturas. Hoehnea, v.35, n.2, p.255-264, 2008.

IBAMA. Instituto Brasileiro de Meio Ambiente. Flora lista oficial de flora ameaçada de extinção. Disponível em: <http://www.ibama.gov.br/flora/extincao.htm $>$ Acesso em: 18 de out. 2008.

LOCHER, R.; BUCHELI, P. Comparison of soluble sugar degradation in soybean seed under simulated tropical storage conditions. Crop Science, v.38, p.1229-1253, 1998.

LORENZI, H. Árvores brasileiras: manual de identificação e cultivo de plantas arbóreas nativas do Brasil. Nova Odessa: Plantarum, 1992. 352p.

MARCOS FILHO, J.M. Fisiologia de sementes de plantas cultivadas. Piracicaba: FEALQ, 2005. 495p.

McDONALD, M.B. Seed deterioration: physiology, repair and assessment. Seed Science and Technology, v.22, n.3, p.531-539, 1999. 
PAULA,N.F.; BORGES,E.E.L.; BORGES， R.C.G.; PAULA,R.C. Alterações fisiológicas em sementes de seringueira (Hevea brasiliensis Muell.Arg.) durante o armazenamento. Revista Brasileira de Sementes, v.19, n.2, p.327-334, 1997.

SANTOS, S.R.G.; PAULA, R.C. Teste de envelhecimento acelerado para avaliação do vigor de lotes de sementes de Sebastiania commersoniana (Baill.) Smith \& Downs (branquilho) - Euphorbiaceae. Revista Instituto Florestal, v.19, n.1, p.1-12, 2007.

SILVA, D.J. Análise de alimentos - métodos químicos e biológicos. Viçosa, U.F.V., Imprensa Universitária, 1990. 165p.
STATSOFT, Inc. STATISTICA (data analysis software system), version 6. 2001. (Software estatístico).

THAPLIYAL, R C; CONNOR, K F. Effects of accelerated ageing on viability, leachate exudation, and fatty acid content of Dalbergia sissoo seeds. International Seed Testing Association, v.25, n.2, p.311-319, 1997.

TRAWATHA, D.E.; TEKRONY, D.M.; HILDEBRAND, D.F.; Soybean lipoxygenase mutants and seed longevity. Crop Science, v.35, p.862-868, 1995.

WETTLAUFER, D.H.; LEOPOLD, A.C. Relevance of Amadori and Maillard products to seed deterioration. Plant Physiology, v.97, n.2, p.165-169, 1991. 